\title{
SETTLEMENT NENETS ON THE YAMAL PENINSULA: WHO ARE THEY?
}

\author{
Elena V. Liarskaya
}

\begin{abstract}
The article is devoted to the present situation on the Yamal Peninsula. At the beginning of the 20th century the majority of Nenets living on Yamal were nomads. Over the last decades, settlement component has become a part of Nenets culture; failure to recognize this component while describing the present state of Nenets culture leads to serious distortions. For a presentday Nenets, life in a settlement is a possible alternative to life in the tundra, whereas the spheres of two ways of life existing in Nenets culture, namely, a tundra life and a settlement life, are spatially separated. It is considered normal when a Nenets belonging to a younger generation possesses both alternatives of culture simultaneously, knows the rules determining the choice of the lifestyle, can effectively perform the switch from one lifestyle to another, and can use both.
\end{abstract}

Key words: Nenets of Yamal, tundra and settlement lives in the Nenets culture.

At the beginning of the 20th century, the majority of Nenets living on the Yamal Peninsula were nomads; only a very small portion of population was compelled to lead a sedentary way of life which was seen as a breach of the normal order of things. To cite the words of the Nenets anthropologist Galina Khariuchi,

Each professional hunter "sitting on one place" (ngamdioda) and not having the freedom to roam from place to place, tried to "raise on reindeer herding - that is, to increase deer livestock, to become a reindeer herder and to live nenei ilngana (lit. 'the real life'). (Khariuchi 2001: 12)

Although situations when even herd owners who possessed thousands of reindeer would lose all their animals, for instance as a result of epizootic, were not at all uncommon on Yamal, in the majority of cases these people were able to continue their usual nomadic way of life and had a chance to restore their herds. What made this possible was a special system of "insurance" and "crediting" in the Nenets culture (for a detailed description of this system, see Evladov 1992: $168-173)^{1}$ 
In the 20th century a number of drastic and abrupt changes were taking place on the Yamal Peninsula, as well as all over the North. As everywhere, the Soviet power was established on Yamal, collectivization was conducted, kolkhozes (and later sovkhozes) were created; at the end of the 1950s the general compulsory school education was introduced, and the politics of sedentarization was under implementation. All these processes could not fail to exert their influence upon the structure of Nenets population. Which particular changes took place?

On the one hand, the number of tundra nomads did not decrease (which was rather unexpected), and at the beginning of the 21st century the nomadic population was even slightly higher than in the 1930 s, before the start of active transformation. ${ }^{2}$ Even more, nomadism on Yamal preserved its family character and all age groups of population were represented in the tundra: people in the working age, the elderly, and children. Thus in general the quantity and the structure of the tundra population did not undergo serious changes. Moreover, the traditional way of life is still seen as something rather prestigious. Yamal is virtually the only region which has not experienced difficulties with young reindeer herders, and the Nenets language on Yamal is probably the only northern language that has retained its firm position (Vakhtin 2001). Therefore, if one considers the situation from the point of view of absolute numbers, then the tundra population of Yamal has not changed in comparison to what it was in the $1930 \mathrm{~s}$. Yet, percentage-wise the number of people living in the tundra has decreased by $50 \%$.

During the last 70 years the indigenous population on Yamal has doubled: while in 1935 only 4,645 Nenets lived here (Krupnik 2000: 145), in 2001 (data collected by the District Committee of Statistics for the state on January 1, 2001) there were 10,052 indigenous people living in the Yamal region (EUYamal-2001). ${ }^{3}$ This happened due to a combination of many factors, and, first of all, due to the improvement of the availability of medical care for the Nenets population and a decrease in mortality rate (Krupnik 2000: 145) against the background of the traditional orientation towards high birth rate.

Thus at the beginning of the 21st century approximately a half of Yamal Nenets continued to live according to the traditional way of life. While leading a tundra (nomadic) life, they are engaged in traditional Nenets economy, live in chums, usually wear ethnic clothes, speak mostly the Nenets language, and their life organization and customs do not essentially differ from those described in the $1920 \mathrm{~s}-1930$ s. $^{4}$

The second half of the Nenets live in settlements rather than the tundra, and are usually engaged in branches of economy new for the Nenets culture. At the beginning of the 21 st century, these were people usually born and raised 
in the tundra, yet later they moved to settlements whether at their own will or owing to various circumstances. Children living in settlements since birth represent a small group of the population. A settlement (sedentary) life implies activities that have been formerly absent in the Nenets culture; in settlements people live permanently in houses, wear mostly European clothes, more often use Russian for communication, and abide by the norms and rules sometimes very different, if not even contradictory, to those accepted in the tundra.

Settlement life has emerged comparatively recently, as a result of interaction with the Russian culture and under duress of the Soviet power and its propaganda of sedentarization and "overcoming cultural backwardness". A similar shift towards a sedentary way of life among the representatives of nomadic peoples and their concentration in settlements has been taking place in other regions of the Far North over the last 70-80 years.

Many authors - writers from the North, scholars, and journalists - discuss the course of this process and its consequences. As a rule, these authors emphasize the intermediary position of this category of population who broke away from traditional culture and occupations, lost ties with people living in the tundra, forgot or are forgetting their language and customs - without, at the same time, becoming "Russian", and thus stay between the two cultures. Residential school system, which the entire population of the region had to go through starting with the second half of the $1950 \mathrm{~s}$, is seen as the major reason behind this situation. Already in the 1970s ethnographers in their reports observed that

[y]outh do not go to work in this branch of economy [reindeer husbandry] because they break away from tundra life during the eight years of their stay in a residential school. Young people attempt to stay in settlements, taking up secondary jobs (Lebedev et al. 1974: 36).

After 20 years, the situation is the same: those who stay in settlements occupy themselves with "non-creative, and, as a rule, secondary and supplementary jobs, and have passive orientation towards activity" (Golovnev 1993: 101-102).

Thus the indigenous population who shifted towards the sedentary way of life is seen mostly as a marginal layer, and this attitude, within the frames of the traditional ethnographic orientation to the study of the "traditional" way of life and thought, results in the fact that Nenets living in settlements and towns do not, as a rule, attract research interest. Even if such people fall into the area of researchers' attention, they are not considered "real Nenets," fully sharing in the traditional Nenets culture. It seems that our field data and published materials allow to slightly correct this attitude and more precisely define the positioning of this group in the Nenets culture. ${ }^{5}$ 


\section{SETTLEMENT NENETS}

From the point of view of Nenets culture there are two theoretically possible attitudes to Nenets living in a non-traditional milieu.

The first attitude is to stop considering them Nenets because they have left the "jurisdiction" of their culture and live according to different rules that have nothing to do with the Nenets culture.

The second attitude is to incorporate the settlement life and its norms into Nenets culture as a possible alternative; to start seeing it not as something imposed on the people from outside, but as a quite possible and admissible variant of "one's own".

To put it differently, in one case culture distances its people, in the other it includes new cultural norms and realities into itself. In our opinion, Yamal represents the second variant of development.

There are several observations that support this assumption.

1. Life in settlement seems to have become one of the admissible variants in the development of life scenario, in contrast to the past when life in the tundra was the only norm for a Nenets. There have been sedentary Nenets for a long time, long before the Soviet time. But, as already mentioned, everybody in these times saw this as a clear deviation from the norm.

When a tundra reindeer herder had lost his herd and was forced to subsist on forest and tundra trade, he, nevertheless, thought of his situation as a temporary one and tried to accumulate reindeer and return back to tundra. (Golovnev 1995: 52)

The major distinguishing feature of settlement Nenets today is that many of them do have an opportunity to roam the tundra (their families have reindeer and pasture them), and they do not consider their presence in settlements as something "temporary and forced", but as "permanent and voluntary".

Today the possibility of such life scenario, in which a person who has grown up in tundra stays to live in a settlement, is not excluded either by the young or by the older generation. It is indicative that even the parents who would prefer their children to live in the tundra, not only recognize their right to live in the settlement but often try to create conditions that would provide for the possibly most successful life in the settlement for their children (of which there are quite many examples). ${ }^{6}$

2. If life in a settlement is one of the possible life scenarios for the contemporary Nenets, what are the reasons determining which place one will choose for dwelling - the tundra or settlement? Widely-spread scholarly and societal no- 
tions about the role that residential schools play in bringing the young generation away from the traditional values and way of life led me to assume that the higher the degree of education, the smaller are the chances that the youth will return to the tundra. The level of schooling of people living in the tundra should be much lower compared to those living in settlements.

This hypothesis did not find confirmation upon its verification. Data collected during our expeditions to Yamal (EU-Yamal 1998, 2001) showed that there is no substantial difference in the level of education between tundra and settlement Nenets: people born in the same decade have roughly the same level of education, regardless of whether they live in tundra or in a settlement. Thus, among people born between 1950 and 1970, 78 per cent of tundra dwellers and 84 per cent of people living in settlements have completed 9 grades of school (including secondary educational institutions). The difference is not as big as one might have expected. Thus, the choice between tundra and settlement as the place of dwelling does not directly depend on the level of education.

However, the analysis of statistical materials, interviews and literature allowed me to assume that for a Nenets the choice between tundra and settlement does not only depend upon his/her personal wish. It seems that there exists a certain set of rules determining the possibility of such a choice.

As is well known, a Nenets household is strictly divided into male and female sphere of activity, and can effectively function only when both of them are present. The lack of a man or a woman makes reindeer herders' life in tundra extremely difficult and may be one of the reasons for moving to a settlement. To preclude this, there exist certain unwritten rules, the essence of which can be reduced to the following:

- If anything happens to the father (mother) in the tundra, he/she should be helped or substituted by the oldest son/daughter.

- This system is not rigid, as, for instance, the law of primogeniture, but is rather flexible: if the oldest brother wishes to continue his education, but there is a younger brother who is already capable of helping their parents, then he may go to the tundra instead of the oldest brother. The same rule applies to girls. Tundra families are large: families of 7-9 children are not rare. While the youngest siblings are still growing up, their elder brothers and sisters often have families of their own, and sometimes even their own households so that it is the younger children who stay with parents to help them.

In accordance with the system described, if nothing goes wrong, parents in the tundra should have at least the same number of children. Within the frame- 
work of such system, the choice of the place of dwelling is the most regulated for the oldest and youngest children, whereas the "middle" children enjoy more freedom. This principle is obvious for Nenets themselves, and they clearly emphasize it in interviews. For instance, a Nenets woman born in 1932 said that when her father had to give one of his children away to school, he chose her, because her position in the family was "in the middle and the least significant for tundra life."

Thus not only Nenets started to consider life in a settlement as a normal way of life, but there emerged a set of rules influencing the distribution of population between tundra and settlements.

3. While analyzing the material collected, I tried to separate data related to the tundra people from the data concerning settlement dwellers. Quite unexpectedly, it turned out that in approximately one third of all the 300 cases under analysis it was impossible to draw the division line. It became clear that the rule assuming a division between "those who live in tundra and belong to tundra culture" and "those who live in a settlement and do not belong to tundra culture" has too many exceptions to it. Apart from the two simplest variants: (1) a person who was born and spent his/her whole life in tundra (or in a settlement), or (2) a person who stayed in a settlement after school (army) and did not return to his/her parents, there exist a multitude of intermediary possibilities. For example:

- A person or a family had lived in tundra, and then for some reason (having grown older, having lost a spouse, or having quarreled with relatives, etc.) permanently moved to a settlement. With all that, they could have lived in the tundra for quite a long period of time, sometimes for several decades.

- A person or a family had lived in a settlement for a long time, worked according to their specialization, and then left to live in the tundra.

- Often there are cases when people who are permanently living and working in a settlement regularly go to the tundra (sometimes for a considerable period of time), where they work as much as the tundra people, helping them to herd reindeer and keep the household.

- Apart from this, there is a category of people who change their place of dwelling depending on the season: for example, in summer they live in the tundra and fish, in winter they live in the settlement and do some kind of permanent work.

In many cases it is very difficult to determine whether a person belongs to the tundra or the settlement culture judging simply by the place of residence. For 
instance, students of residential schools live most of their life in a settlement, yet are considered to be the tundra people both by those who live in settlements, and by the people living in tundra themselves.

All this confirms the fact that the ties between the settlement and tundra parts of the indigenous population are not disrupted, that there are regular and intense contacts between them, and that one and the same person may move from the tundra to a settlement and back several times during his/her life.

All the above means that the Nenets community may not be divided, as it is usually done, into only tundra and only settlement dwellers, because such division fails to fully reflect the existing reality. In a sense, there is no clear borderline between tundra and settlement Nenets, precisely because of the existence of all the intermediary categories and the provisional character of attachment to the tundra or to the settlement. The Nenets' society may be represented as a certain continuum, the one pole of which is occupied by those not very numerous Nenets whose contacts with "civilization" are rendered minimal, and by a small group of people who have virtually lost connection with the tundra culture. In-between one finds the categories of people who maintain close relations with a different side, or, in general, act either as tundra dwellers or inhabitants of settlements.

4. The idea of division between tundra and settlement Nenets has not emerged out of nothing; this is not an abstraction, introduced by researchers, but a reality created by the consciousness by the Yamal people themselves. One can surmise that this idea was called forth by the fact that life in the tundra and in the settlement are very distinctive and opposed to each other in the consciousness of both the Nenets and people arriving from other places. In the tundra and in settlements people live under different conditions and to different rhythms, according to widely different laws and norms, wear different clothes, engage themselves in different activities, and usually speak different languages.

Each variant of culture, fostered both in the tundra and in settlements, have its own set of ideas, norms and rules, which often differ and even contradict each other. Yet with all that there are ideas, norms and rules that are common to both cultural variants. For instance, the system of Nenets' personal names is the same for both variants, as well as the set of notions and practices connected with the concept sia"mej (particular impurity) that function both in the tundra and in settlements. The majority of Nenets wear ethnic clothes, remain loyal to ethnic dishes (first of all, to raw meat and blood, which have recently started to turn into symbols of the Nenets culture). All this unites them as well, and allows them to regard tundra and settlement 
variants not as isolated, but as two constitutive parts of one culture - notwithstanding all their differences.

The borderlines between the spheres where this or that variant of culture is used are clearly understood by the Nenets. They know that settlement life is constructed according to laws different from that in tundra. Yet apart from this opposition, one can discern a tendency to regard both types of behavior, in tundra and in a settlement, as "correct".

We have recorded a series of stories told by Nenets women about how they came to the residential school and had to go to the bathhouse for the first time between 1940 and the 1990s (EU-Yamal 1998, 2001). While describing this episode, the majority of girls and women recalled that the bathhouse instilled fear in them - not because they had to wash themselves but because they had to get undressed and wash in front of everybody, which went against the tundra ideas and norms. The children's fear was totally incomprehensible for Russian female teachers. However, what is interesting is that recently Nenets female teachers have started to participate in the process of washing; these are women, who, although they understand the children's feelings, consider washing in the bathhouse a necessary element of settlement life. (In other words, from the point of view of tundra people, they behave as Russians. This attitude finds its expression in children's language. All female teachers and nurses, irrespective of their ethnic background, are called luchene, lit. 'Russian woman'). Quite accidentally, there was a tundra family among our informants; their mother had worked in a residential school in her youth, and, consequently, was a luchene, and took part in the bathhouse ordeal. Later she married a reindeer herder and moved to the tundra. It is very indicative that the stories about the first washing in the bathhouse recorded from her children do not in any way differ from other stories about her: having moved to the tundra, she raised her children not as luchene (i.e., according to settlement rules), but in accordance with tundra customs.

Thus we arrive at a conclusion that if a person can move from the tundra to the settlement and back for several times, and each move is accompanied with the change of cultural norms, then one and the same person can represent both tundra and settlement ways of life in the Nenets culture.

5. We have already mentioned that life in a settlement is constructed according to one set of rules, and life in the tundra complies with another, and that the borderline between the two spheres is very well distinguished by the Nenets. The crossing of this border never remains unnoticed and is always marked, e.g., by the change of clothes, and, in many cases, by the language of communication. 
For example, the contemporary Nenets wear two types of clothing: ethnic and European. ${ }^{7}$ Furthermore, they have developed a tendency to differentiate them by using ethnic clothes predominantly in the tundra, and European clothing mostly in settlements. Ethnic clothes have started to symbolize belonging to the tundra Nenets culture. Thus, by putting on European clothes, a Nenets manifests that at this point he/she should be regarded as a member of settlement culture. Often this is done consciously: for instance, now, sending children to school, Nenets parents dress them in European clothes, thereby emphasizing the change in their status. ${ }^{8}$ According to one female informant, her parents tried to change clothes even for a short trip to the settlement, so that everybody around could see that they are not tundra people and would not think that they will fall victim to fraud (for example, at a store).

A contrary situation might occur as well, when a Nenets puts on ethnic clothes in a town or a settlement, in order to stand out from people around and to stress his/her belonging to Nenets culture. One of my Nenets interviewees, upon my suggestion to take her picture in Salekhard, purposefully put on a jagushka (a type of Nenets female ethnic clothing) and agreed to take picture only while wearing it. The motivation was that she is a Nenets woman and wants people looking at the picture be reminded of it. ${ }^{9}$

According to Galina Khariuchi, young Nenets tundra people have European outfits which they put on when coming to a settlement. At the same time, the majority of Nenets, irrespective of the place of their dwelling, not only possess ethnic clothes, but wear them when they go to the tundra. Thus in the Nenets consciousness each type of clothing is a marker of a certain cultural variant. As a result, it is normal to change one variant of culture when moving from the tundra to a settlement, for example, by changing into a different type of clothes.

Such correlation between the type of clothing and the variant of culture "in use" may be observed in other regions as well. An article by Charles W. Hobart (1970) compares the Yamal Nenets and the situation of Canadian Eskimos in the 1960s. The author argues that children returning from residential schools to their settlements refused to wear ethnic Eskimo clothes and footwear and preferred wearing European clothes, although it did not sufficiently protect them from cold, and this resulted in several tragic accidents. This was a testimony that children refused to see themselves as the same Eskimos as their parents, that they wanted to contrast themselves to them. The author says that this was motivated by the fact that children felt more educated and more cultural in comparison to their parents (Hobart 1970: 131-135). Children wanted to emphasize their sharing in the 'white world', which, from their point of view, was more prestigious, whereas their return to tundra was seen as a 'step 
back.' Both on Yamal and in Canadian Arctic clothes of certain kind serve as the marker of belonging to a specific type of culture. The difference in the use of markers reflects the difference in cultural situations. While the relationships described by Hobart were clearly hierarchical, and the 'white' culture enjoyed a privileged status, the ease in changing clothes on the Yamal Peninsula suggests a certain equality of both cultural variants existing there.

Another example is connected with the use of the Nenets language. ${ }^{10}$ This language is widely-spread and effectively functions in the Yamal tundra. This is the language used in discussions of household activities, in talks with the visiting neighbors, and in sharing the news - this is the language taught to children. Yet it would seem that in the Nenets consciousness (among both tundra and settlement dwellers), their language is tightly connected with one's place of habitation, and the Nenets language is seen first of all as the language of people living in the tundra. Usually, the Nenets who have a good command of both languages use Russian in settlements more often than in the tundra. Frequently parents born in the tundra and living in a settlement or a town explain their children's lack of command of the Nenets language by the fact that the children do not live in the tundra, and consequently, have no chance of knowing it,

One can learn [to speak] the Nenets language very well, but only in the situation of roaming in the tundra! In the tundra one can certainly learn to speak one's own language within a month. But in the Russian house it is impossible! (EU-Yamal 1998, VNN).

An interesting situation can be observed in those families which used to live in a settlement and then moved to the tundra. There are two descriptions of such cases in our materials. In both accounts, the language of communication was Russian while the family lived in the settlement. When the family moved to the tundra, this language started to change, and quite fast at that:

When I was small, I spoke Russian. When we moved to tundra, this was in 1989 [...] me, my sister and Vera, we always kept silence, we couldn't speak the Nenets language. ${ }^{11}$ Later we got used to [a different language]. (EU-Yamal 1998, resident school pupil, born in 1982)

The change of language seems to have been rather drastic and had disturbed normal family communication for a certain period of time; had that been different, and had the Russian language retained any place in the new milieu, the following situation would not have had any chances to occur:

Only my sister Vera [the younger sister of the narrator] she [...] Once our mother thought she became dumb, she always kept silent, yet it turned 
out that she gradually, to herself, probably studied the Nenets language. And [she] started to speak the Nenets... (EU-Yamal 1998, resident school pupil, born in 1982)

Thus the transition from one sphere or world to another is usually accompanied by the change of language of communication, clothing, and norms regulating everyday life (with one reservation: this pertains only to the generations of Nenets under 60 and is not valid to people older than that). The lack of changes during the transition from tundra to a settlement/town and back is seen as a breach of the existing cultural rules.

To conclude it can be said that over the last decades settlement component became a part of Nenets culture; failure to recognize this component while describing the present state of Nenets culture leads to serious distortions.

For a present-day Nenets life in a settlement is a possible alternative to life in the tundra, whereas the spheres of two ways of life existing in Nenets culture, namely, a tundra life and a settlement life, are spatially separated. The choice between living in the tundra and in the settlement is not directly connected with the level of education, and depends on personal preference, though it is still in accordance with established rules. With all that, (1) the choice between tundra and settlement is not final, and may be made several times during one's life course, and (2) the same people may represent both variants of culture. The tundra and settlement ways of life are constitutive parts of a single culture. Both ways of life are more or less equal, yet their mutual relations are quite complex. The tundra and the settlement ways of life are clearly separated from each other and counterpoised in the Nenets consciousness. Yet this does not preclude regarding both ways of life as reciprocally connected.

Firstly, because there are notions equally relevant for the Nenets living both in tundra and in settlements. Secondly, because apart from the two ways of life themselves, there are rules determining the choice between them and the use of a particular way of life in a particular situation. The switch from one way of life to another is often accompanied by the switch of language and clothing; the latter is probably the clearest marker of the whole situation change. It is considered normal when a Nenets, belonging to a younger generation, possesses both alternatives of culture simultaneously, knows the rules determining the choice of the lifestyle, and can effectively perform the switch from one lifestyle to another.

Accordingly, the notions of Nenets themselves as to who today may be considered a real Nenets, include elements of both variants.

A real Nenets must be a procurer. [...] A real Nenets [...] he should be able to drive a snowmobile, to ride a reindeer, not to get lost in blizzard. 
That's what I think. All aspects. He should be [...] should know how to do both field and tundra work, that's how I understand it [...] Yes, and [...] [he] should know how to put on a malitsa ${ }^{12}$ and to go [...], let's say, to help relatives, and to go by the first call. (EU-Yamal-2001, SLH)

Similar accounts are given by Galina Khariuchi. For example, a Nenets who is living in town said:

In the town I feel myself Russian, because I do not differ from them in clothes, I drive my own car, have my own house. In the tundra I ride on reindeer, skillfully manage them and feel myself a Nenets. (Khariuchi 2001: 169)

According to data provided by Galina Khariuchi, which find support in our own field materials, "there has not yet formed a sufficiently representative group of Nenets ethnos that would be completely broken off of their relatives - reindeer herders, fishers, hunters - and would not experience necessity in constant contacts with them" (Khariuchi 2001: 194). Apart from cultural ties, the unity between these groups is maintained by close economic and social contacts, as well as by various forms of mutual help and cooperation.

The data presented in this article may not be extrapolated upon cultural processes taking place in other territories of the Far North, because each particular region has its own specific situation.

Translated by A. N. Kushkova European University at St Petersburg

\section{NOTES}

1 On this system see also Khariuchi 2001: 12-13; Yadne 1995: 201-202.

2 According to data provided by Igor I. Krupnik there were 4,645 Nenets on Yamal in 1935 (Krupnik 2000: 145). According to data collected by the Yamal District Committee of Statistics for January 1, 2001, the indigenous nomadic population of Yamal amounted to 5,407.

3 In citations of field materials the following abbreviations have been used: EU archive of the European University at St. Petersburg, followed by the place and year of recording, and, occasionally, initials of informants.

${ }^{4}$ See, for example, archives of the Museum of Anthropology and Ethnography, Russian Academy of Sciences, Fund 2 (G. D. Verbov); Evladov 1992.

5 The article is based on the results of two expeditions to Yamalo-Nenets National Okrug in 1998 and 2001. The expeditions were supported by the European Univer- 
sity at St Petersburg. The research included participant observation in a residential school, settlements, and the tundra as well as informal interviews that were conducted with the people who belong to several generations of Nenets.

${ }^{6}$ To give only one example: A Nenets woman, whose family possesses a large reindeer herd and who spent her whole life roaming the tundra, explained that they also have an apartment in case their son would like to live in the settlement. While both she and her husband are hoping that their boy will stay in tundra and become a reindeer herder, the possibility of his own independent choice is not ruled out. Moreover, the parents take steps in order to provide for better starting opportunities for their son in case he makes this choice.

7 Mostly outdoor clothes and footwear.

8 In the past the change of clothes in the school was done against the will of the child and his/her parents (EU-Yamal 1998, 2001).

9 Another example is the celebration of the Reindeer Herder's Day. In everyday settlement life, the Nenets usually do not put on traditional clothes. Yet judging by the stories collected, during the annual Reindeer Herder's Day everybody is trying to put on their best Nenets clothes, thus stressing their sharing in the Nenets culture.

${ }^{10}$ For a short review of the situation of the Nenets language and the varying degrees of the use of the native language as a language of instruction in school and in education generally, see e.g. Vakhtin 2001, Liarskaya 2003, Vakhtin \& Liarskaya 2004.

${ }^{11}$ An explanation should be provided here. The family switched to the Nenets language not because it is prohibited to pronounce Russian words in the tundra, but because the usual language of people's communication in the tundra is Nenets. In both cases mentioned, the family did not have its own separate chum in the beginning, and had to live together with acquaintances who naturally spoke the Nenets language among themselves.

${ }^{12}$ A type of male clothing of the ethnic Nenets.

\section{REFERENCES}

Evladov, Vladimir P. 1992. Po tundram Iamala k Belomu ostrovu (Ekspeditsiia na Krainii Sever poluostrova Iamal v 1928-1929 gg.). [Toward the Belyi Island through the Yamal Tundra (Expedition to the Far North of Yamal 1928-1929).] Tiumen: IPOS RAN.

Golovnev, Andrei V. 1993. Model'obrazovaniia. In: A. Golovnev (ed.) Kasum-Ekh. Materialy dlia obosnovaniia pro-ekta etnicheskoi statusnoi territorii. [Model of Education. Kasum-Ech. Why the Project for Establishment of Ethnic Status Territory is Needed?] Shadrinsk: PO Iset'.

Golovnev, Andrei V. 1995. Govoriashchie kul'tury: traditsii samodiitsev i ugrov. [Talking Cultures. Traditions of Samoyeds and Ugrians.] Ekaterinburg: UrO RAN.

Hobart, Charles W. 1970. Report on Canadian Arctic Eskimos: Some Consequences of Residential Schooling of Eskimos of Canadian Arctic. Arctic Anthropology. Vol. 6, No 2. pp. 123-135. 
Khariuchi, Galina P. 2001. Traditsii $i$ innovatsii v kul'ture nenetskogo etnosa (vtoraia polovina XX veka). [Traditions and Innovations in the Culture of the Nenets Ethnos.] Tomsk: Izd. Tomskogo Universiteta.

Krupnik, Igor 2000. Liudi v chumakh, tsifry na bumage: Russkie istochniki k demograficheskoi istorii Yamala, 1965-1992 gg. Drevnosti Iamala. [People in the Tundra, Figures on Paper. Russian Sources on the Demographic History of Yamal. Antiques of Yamal.] Ekaterinburg \& Salekhard: IIiL UrO RAN.

Lebedev V. \& Lopulenko N. \& Simchenko, Y. 1974. Khoziaistvo, byt' i kul'tura naseleniia Avamskoi tundry po materialam Taimyrskogo otriada Severnoi ekspeditsii. Novoe v etnograficheskikh $i$ antropologicheskikh issledovaniiakh: itogi polevykh rabot instituta etnografii $v 1972 \mathrm{~g}$. [Economy, Everyday Life and Culture of the Inhabitants of the Avams Tundra. The Latest Results of Ethnographical and Anthropological Research in 1972.] Ch 1, pp. 32-41.

Liarskaya Elena V. 2003. Severnye internaty i transformatsiia traditsionnoj kultury (na primere Nentsev Jamala). Dissertacija na soiskanie uchenoj stepeni kandidat istoricheskih nauk. [Northern Residential Schools and the Transformation of Traditional Culture. The Case of the Yamal Nenets. Dissertation.] St Petersburg. Vakhtin, Nikolai 2001. Iazyki narodov Severa v XX veke. Ocherki iazykovogo sdviga. [Languages of Peoples of the North in the 20th Century. A Study of Language Shift.] St Petersburg: Dmitrii Bulanin.

Vakhtin, Nikolai \& Liarskaya, Elena 2004. Jasykovaja situacija i problemy obrasovanija. Sovremennoe polozhenie i perspektivy razvitija malochislennych narodov Severa, Sibiri i Dal'nego Vostoka: nezavisimyj ekspertnyj doklad / pod red. V. A. Tiskova. [Language Situation and Problem of Education. In: V.A. Tishkov (ed.) Current Situation and Development Prospects of Native Minorities of the North, Siberia and Far East. Independent Expert Report.] Novosibirsk: Izdatel'stvo Instituta Antropologii i Etnologii Sibirskogo Otdeleniia Rossiiskoi Akademii Nauk, pp. 133-148.

Yadne, Nina N. 1995. Ia rodom iz tundry: kniga pervaia. [I was Born in Tundra. Book 1.] Tiumen: Softdesign. 